\title{
OSL age determinations of Pleistocene fluvial deposits in Central Amazonia
}

\author{
EMÍLIO A.A. SOARES ${ }^{1}$, SONIA H. TATUMI ${ }^{2}$ and CLAUDIO RICCOMINI ${ }^{3}$ \\ ${ }^{1}$ Departamento de Geociências, Universidade Federal do Amazonas \\ Av. Gal. Rodrigo O.J. Ramos, 3000, 69077-000 Manaus, AM, Brasil \\ ${ }^{2}$ Faculdade de Tecnologia de São Paulo, Praça Cel. Fernandes Prestes, 30, 01124-060 São Paulo, SP, Brasil \\ ${ }^{3}$ Departamento de Geologia Sedimentar e Ambiental, Programa de Pós-Graduação em Geoquímica e Geotectônica \\ Instituto de Geociências, Universidade de São Paulo, Rua do Lago, 562, 05508-080 São Paulo, SP, Brasil \\ Manuscript received on February 17, 2009; accepted for publication on July 21, 2009
}

\begin{abstract}
Absolute dating methods have been used in chronological studies of geological processes and sedimentary units of Quaternary age in Central Amazonia, Brazil. Although radiocarbon dating has been very useful in archaeological research and soil studies, the temporal interval of this method is inefficient in evaluating the sedimentation aspects and geological events from the beginning of the Quaternary in the Amazon basin. The use of crystal luminescence dating has been one of the most promising tool for determining the absolute dating of Quaternary deposits in the Amazonian region. Optically stimulated luminescence (OSL) dating, following the MAR and SAR protocols, in a tectonic-sedimentary study of Quaternary fluvial deposits in the confluence area of the Negro and Solimões rivers, indicated ages from 1.3 (Holocene) to about 67.4 kyears (Late Pleistocene) for these sediments. Low radioactive isotope concentrations were found about $2 \mathrm{ppm}$ for ${ }^{235} \mathrm{U}$ and ${ }^{238} \mathrm{U}$; $5 \mathrm{ppm}$ for ${ }^{232} \mathrm{Th}$; and the ${ }^{40} \mathrm{~K}$ concentrations were almost zero. A comparison was made between MAR and SAR protocols taking into account the fluvial depositional process.
\end{abstract}

Key words: crystal luminescence dating, Quaternary, fluvial terraces, Central Amazonia.

\section{INTRODUCTION}

The stratigraphy of Cretaceous and Cenozoic deposits in the Amazon basin has not yet been completely established due to the lack of geochronological dating. Isolated measurements based on palynomorphs allowed age-determinations of some intervals of Cretaceous and Miocene units, while radiocarbon dating is restricted to the most recent time-interval of the Quaternary. Furthermore, the lack of sedimentary and stratigraphic studies has avoided the means by which to adequately analyze inter and intra-basin correlations among Quaternary deposits. These deposits are relatively thick, reaching tens of meters, and have become homogenized due to weathering. A large part of Quaternary deposits in the confluence zone of the Negro and Solimões rivers has been

Correspondence to: Emílio Alberto Amaral Soares

E-mail: easoares@ufam.edu.br correlated to the Solimões (Miocene) and Içá (PliocenePleistocene) formations from the Solimões basin (Lourenço et al. 1978, Franzinelli and Piucci 1988, Franzinelli and Latrubesse 1993, Franzinelli and Rossi 1996, Franzinelli and Igreja 2002, Latrubesse and Franzinelli 2002, Carta Geológica do Brasil ao Milionésimo 2004).

Radiocarbon dating has served as the world reference standard for almost five decades, greatly facilitating the understanding of the dynamics of terrestrial systems developed over the last 20,000-30,000 years (Blum and Törnqvist 2000). However, the use of radiocarbon dating for Amazonian fluvial deposits is still limited (Latrubesse and Franzinelli 1998, 2002, Rossetti et al. 2005), and many records remain poorly understood. In part, this is due to a lack of organic material, especially in reference to the older alluvial deposits, which have been intensely weathered. The other factor is the limiting nature of 
the radiocarbon dating method, which is inefficient for records older than 40,000 years.

In the last few decades, absolute dating of Quaternary deposits in Brazil has involved the use of the crystal luminescence method (J.C. Stevaux, unpublished data, S.R. Dillenburg, unpublished data, Suguio et al. 2003, Gianinni et al. 2003, Tatumi et al. 2006, among others). Although, in the Amazon the use of this technique is still fairly new (Carneiro-Filho et al. 2002, Teeuw and Rhodes 2004, Tatumi et al. 2007), it has been shown to be efficient in analyses of Quaternary deposits taken from regions around the cities of Manaus and Manacapuru. In this study, quartz crystals were dated utilizing the OSL method using single (SAR) and multiple aliquots regeneration (MAR) protocols (Murray and Wintle 2003). Age results were correlated to the migration of past fluvial systems in the region.

\section{QUATERNARY GEOCHRONOLOGICAL ASPECTS IN THE AMAZON}

The chronology of the main geological processes of the Quaternary can be calibrated with measurements of short and middle half-life radioisotope concentrations. In the Amazon, the ${ }^{14} \mathrm{C}$ method has been effectively used to date carbon included in ceramic fragments and organic carbon remains from archaeological sites (Petersen et al. 2001, Hornborg 2005, Machado 2006, Schaan 2007) and soils (Sanford et al. 1985, Saldarriaga and West 1986, Bassini and Becker 1990, Santos et al. 1999a, Freitas et al. 2001, 2002), as well as identifying intervals of paleoclimatic changes (Absy 1982, Martin et al. 1993, Turcq et al. 1993, 1998, Behling et al. 2001). The chronological interval of the ${ }^{14} \mathrm{C}$ method, which is restricted to the last thirty fo forty thousand years, has limited the study of older deposits from Amazonian fluvial systems. Furthermore, the validity of previous age measurements for these deposits is now questioned, as well as the resolution of the ${ }^{14} \mathrm{C}$ method being insufficient for accurately dating such older deposits. Also, if collections were taken from areas close to the surface, these deposits could become contaminated by organicrich soil material (Irion et al. 2005). Considering these limitation, dating by crystal luminescence has become one of the most promising tools for determining absolute age of diverse Quaternary sedimentary deposits (Suguio et al. 2003, Gianinni et al. 2003, Barreto et al. 2004, D. Bentz, unpublished data, Tatumi et al. 2006), including those from fluvial systems (Page et al. 1996, Fuller et al. 1998, Mozzi et al. 2000, Nanson et al. 2005, Sylvia and Galloway 2006).

The methods of thermoluminescence (TL) and optically stimulated luminescense (OSL), following the MAR protocol, have been used for dating aeolian paleodunes in the middle Negro river (Carneiro-Filho et al. 2002, Teeuw and Rhodes 2004) and overlying sediments of the Barreiras Formation in northeastern Pará State (Tatumi et al. 2007). The application of the OSL method, in accordance with the MAR and SAR protocols, has also proved to be efficient in the study of Quaternary fluvial deposits from the confluence area of the Negro and Solimões rivers in Amazonas State (E.A.A. Soares, unpublished data) (Fig. 1). In the present study, the association of geochronological data with sedimentary and stratigraphic analyses has set the foundation for interpreting regional tectonics dating back to 420,000 years, as well as the evolution of fluvial dynamics over the last 62,000 years. These developments, in turn, have created new perspectives for understanding the last phase of sedimentation in the Amazon basin.

\section{GEOLOGICAL SETTING}

Evidence of the Quaternary tectonic and sedimentary history of the Solimões-Amazon river system is registered in fluvial terrace deposits found in the confluence zone of the Negro and Solimões rivers, developed over the Cretaceous (Alter do Chão Formation) and Neogene (Novo Remanso Formation) siliciclastic units (Fig. 1). Extensional tectonics originated tectonic depressions that have controlled the Pleistocene sedimentation influenced by Solimões river (Paraná do Ariaú - GPA and Lago do Miriti - GLM grabens) and Negro river (Cacau do Pirera - GCP and Cachoeira do Castanho - GCC grabens) dynamics.

The fluvial terraces of GPA e GCC are related to secondary meander systems with the development of floodplain, whereas the GCP and GLM served as restricted flooded zones with the predominance of suspension sedimentation. The Pleistocene units occur in three levels of terraces. The Negro river always exhibited a straight channel style, confined in basement Cre- 


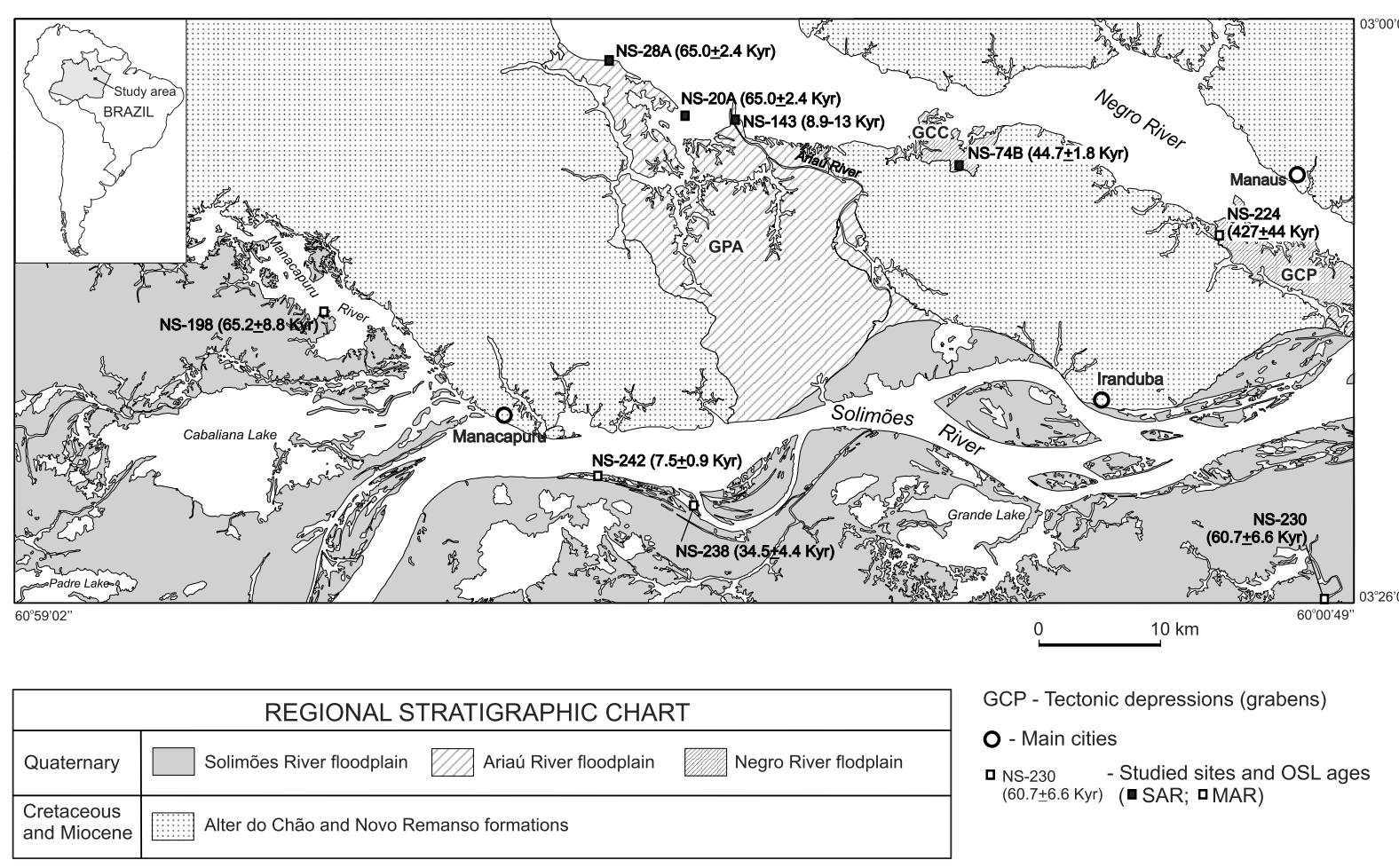

Fig. 1 - Geological setting and location of studied sites.

taceous and Miocene rocks and with restricted alluvial plain, whereas the fluvial pattern of the Solimões river has changed during the Holocene. The terraces of Solimões river show scroll-bars morphology with inclined heterolithic stratification, indicating a meandering channel pattern.

During the Late Pleistocene and Early Holocene, sea level rise, together with the change to a more humid climate, caused an increased aggradation rate of suspended fine-grained sediments that allowed a greater cohesion of channel margin stabilized by the growth of abundant vegetation. Such conditions favored the development of the current anastomosing-anabranching style of the Solimões-Amazonas system.

\section{METHODS}

For OSL dating procedure, the samples were collected with PVC and aluminum tubes of $25-50 \mathrm{~cm}$ in length, and $5 \mathrm{~cm}$ in diameter at the locations shown on the geological map (Fig. 1). All the samples are sediments deposited by fluvial system, and those collected at high points of the terrace, where the water contents are about $2-3 \%$, and they did not remain immersed during long periods of the year. However, for 5 samples we considered water saturated content and the samples were submerged during half year; therefore, we adopted the value of $15 \%$ in these cases (Table I).

Pure quartz grains of $180-250 \mu \mathrm{m}$ in grain size were separated after being treated with $\mathrm{H}_{2} \mathrm{O}_{2}$ for 4 hours, $20 \% \mathrm{HF}$ for $45 \mathrm{~min}, 20 \% \mathrm{HCl}$ for 2 hours, and heavy liquid (SPT) treatments. Feldspar crystals were not observed in the samples during a test using OSL measurements with IR stimulation. OSL measurements were recorded with a model 1100-series automated TL/OSL system, of Daybreak Nuclear and Medical Systems Inc. For quartz stimulation, green and blue lights were applied and the OSL signal detected with a U-340 optical filter. The samples amounts were weighted before each measurement for intensities normalizations. Gamma irradiations were carried out with a ${ }^{60} \mathrm{Co}$ source delivering $(110.0 \pm 5.5) \mathrm{mGy} / \mathrm{s}$, and lucite plates were used to provide the charge particle equilibrium in the sample.

Radioactive contents of the sediments were determined by gamma-spectroscopy with an portable inspector spectroscopy workstation (Canberra), equipped with a $\mathrm{NaI}(\mathrm{Tl})$ detector, model $802-2 \times 0.5$. Crystal size was 
TABLE I

Radioactive isotope concentrations of the samples, water content, paleodose (P) by MAR, cosmic radiation contribution (ADc.r.), total annual dose rate (AD) and ages by MAR and SAR protocols.

\begin{tabular}{|c|c|c|c|c|c|c|c|c|c|}
\hline Sample & $\begin{array}{c}\mathrm{U} \\
(\mathrm{ppm})\end{array}$ & $\begin{array}{c}\text { Th } \\
(\mathrm{ppm})\end{array}$ & $\begin{array}{c}\mathrm{K}-40 \\
(\%)\end{array}$ & $\begin{array}{c}\text { Water } \\
\text { content } \\
(\%)\end{array}$ & P (Gy) & $\begin{array}{l}\text { ADc.r. } \\
(\mu \mathrm{Gy} / \mathrm{a})\end{array}$ & $\begin{array}{c}\mathrm{AD} \\
(\mathrm{Gy} / \mathrm{ka})\end{array}$ & $\begin{array}{l}\text { Age (ka) } \\
\text { MAR }\end{array}$ & $\begin{array}{c}\text { Age (ka) } \\
\text { SAR }\end{array}$ \\
\hline NS-20A & $1.90 \pm 0.25$ & $4.95 \pm 0.18$ & $0.14 \pm 0.02$ & 2 & $53 \pm 12$ & 178 & $1.16 \pm 0.9$ & $45.6 \pm 14.0$ & $65.0 \pm 2.4$ \\
\hline NS-28A & $0.99 \pm 0.08$ & $2.22 \pm 0.08$ & $0.07 \pm 0.02$ & 2 & $36.6 \pm 8.6$ & 178 & $0.66 \pm 0.04$ & $55.3 \pm 16.3$ & $65.0 \pm 2.4$ \\
\hline NS-74B & $1.80 \pm 0.21$ & $4.38 \pm 0.16$ & $0.84 \pm 0.12$ & 15 & $76 \pm 10$ & 178 & $1.56 \pm 0.19$ & $48.6 \pm 12.3$ & $44.7 \pm 1.8$ \\
\hline NS-143 & $2.04 \pm 0.22$ & $5.79 \pm 0.21$ & $0.31 \pm 0.05$ & 15 & $8.7 \pm 1.8$ & 178 & $1.25 \pm 0.12$ & $7 \pm 2$ & $8.9-13.0$ \\
\hline NS-268 & $2.13 \pm 0.13$ & $6.30 \pm 0.23$ & $0.79 \pm 0.11$ & 15 & $2.3 \pm 0.4$ & 178 & $1.71 \pm 0.16$ & $1.3 \pm 0.4$ & $1.6 \pm 0.1$ \\
\hline NS-198 & $1.75 \pm 0.04$ & $5.27 \pm 0.13$ & $0.02 \pm 0.01$ & 2 & $68.2 \pm 7.2$ & 198 & $1.05 \pm 0.03$ & $65.2 \pm 8.8$ & \\
\hline NS-230 & $1.45 \pm 0.03$ & $4.37 \pm 0.11$ & $0.01 \pm 0,01$ & 3 & $53.9 \pm 4.3$ & 198 & $0.89 \pm 0.26$ & $60.7 \pm 6.6$ & \\
\hline NS-242 & $1.58 \pm 0.04$ & $4.76 \pm 0.12$ & $0.01 \pm 0.01$ & 15 & $6.4 \pm 0.5$ & 198 & $0.85 \pm 0.03$ & $7.5 \pm 0.9$ & \\
\hline NS-238 & $1.66 \pm 0.04$ & $4.98 \pm 0.13$ & $0.08 \pm 0.01$ & 15 & $32.4 \pm 3.1$ & 198 & $0.94 \pm 0.03$ & $34.5 \pm 4.4$ & \\
\hline NS-224 & $0.70 \pm 0.02$ & $2.10 \pm 0.05$ & $0.01 \pm 0.01$ & 2 & $229 \pm 20$ & 198 & $0.54 \pm 0.09$ & $427 \pm 44$ & \\
\hline NS-030 & $1.84 \pm 0.04$ & $5.69 \pm 0.04$ & $0.02 \pm 0.001$ & 2 & $284 \pm 26$ & 198 & $1.10 \pm 0.26$ & $249 \pm 30$ & \\
\hline
\end{tabular}

$51 \times 13 \mathrm{~mm}$, and a lead shield was used, model 727 (Canberra). Each sample contained $100 \mathrm{~g}$ and was measured for 7 days. To calibrate the method, four standard soils samples were used (JR-1, JB-3, JG-1a and JG-3) and the applied energy peaks were: 295,609 and $1120 \mathrm{keV}$ for U; 338 and $2620 \mathrm{keV}$ for Th; and $1460 \mathrm{keV}$ for $\mathrm{K}$. Cosmic rays contribution was measured in situ $\left(\mathrm{S} 01^{\circ}\right.$ $28.894^{\prime}$; W $048^{\circ} 27.207^{\prime}$ ), giving a value of $178 \mu \mathrm{Gy} /$ year, and for another sampling sites the rate was corrected by equations cited in Prescott and Hutton (1994).

A total of eleven samples were dated by MAR, and five samples were selected to be dated by SAR (Murray and Wintle 2000, 2003). In the adopted MAR protocol, using the total regeneration method, all the aliquots (with the exception of the natural aliquots, about 10) are bleached to near zero by sunlight exposure during 16 hours and then given laboratory doses. Preheating temperature was chosen after a series of experiments with effects of preheating at 200,220 and $240^{\circ} \mathrm{C}$ on the regenerative signals; these experiments demonstrated that the temperatures of $200^{\circ} \mathrm{C}$ yielded the most reproductive paleodoses. Following preheating, the OSL shine down curves of the aliquots were measured, the late-light regions were subtracted (Aitken and Xie 1992), and the paleodose values were obtained by direct comparison of the natural OSL with the ones resulting from artificial irradiations.

SAR protocols were performed following Murray and Wintle (2000). Preheating temperature was the same used for MAR protocol. Test for dose recovery was performed and the results showed that recovered dose matches the given dose. For the paleodose determinations, at least 20 aliquots were measured per sample.

\section{RESULTS AND DISCUSSION}

In order to study fluvial system deposits in the Amazon, geochronological data obtained by radiocarbon dating and crystal luminescence should be associated with reliable stratigraphic analyses. Samples must be collected from layers that do not show signs of them being re-exposed, reworked or contaminated by surficial processes, which means all factors that compromise the efficiency of the used methods. Elevated levels of precipitation, humidity and weathering (predominantly chemical) in tropical regions can cause erroneous dating calculations. For example, in radiocarbon dating, the contamination of a sample by present-day carbon can result in mistaking a much older sample for a younger one (Santos et al. 1999a, b). Therefore, the application of radiocarbon dating should be restricted to more recent units.

Conversely, high rates of weathering can accelerate the processes of mineral alteration and remobilization of radioactive elements (thorium, uranium and potassium40), which can cause an imbalance in the decayment of radioactive isotopes, thereby impairing the ability to date using the crystal luminescence method (Nanson et al. 2005). In the OSL method, concentrations of radioactive material, which surround the periphery of the grains, are considered to remain constant over the time. If the quantities of these elements diminish over time due to 
dissolution and/or remobilization caused by interstitial solutions, the calculated age could be determined to be older than the actual age because of an underestimation of the actual radiation rate.

A typical calibration curve obtained for the samples employed in this study using MAR displays an exponential growth with saturation. Figure 2 shows an example curve obtained for sample NS-74B, with the paleodose of $76 \pm 10 \mathrm{~Gy}$. The paleodose uncertainties adopted for MAR are the standard deviation of the mean. Although the natural fluctuations in TL levels are large, the OSL values of aliquots recuperated with irradiation in the laboratory oscillated with the same uncertainty observed in natural OSL conditions. Therefore, either the OSL signal of the sample had not decayed homogeneously during deposition, or this fluctuation is due to intrinsic properties associated with defects found within the grains. The uncertainties of $\mathrm{P}$ were found to be approximately $20 \%$, with the exception of NS-143, which was $44 \%$ (Fig. 3). These percentages will be later discussed in reference to the results of the SAR experiments. The P results and dating measurements in accordance with the MAR are shown in Table I.

Equivalent dose, $\mathrm{D}_{\mathrm{e}}$, was evaluated by SAR, and the age histogram frequencies were fitted with Gaussian equation; in the cases when it was observed a broad distribution, the outliers are omitted from the calculation. The number of the aliquots ranges from 12 to 19 .

In Figure 3a, one can observe that almost symmetrical frequency of the ages was obtained, for sample NS$20 \mathrm{~A}$, after the adjustment of the data to a Gaussian distribution. The average age of the sample was calculated at $63.3 \pm 2.4$ kyears. The correct age using Gaussian fitting is most likely $65.0 \pm 2.4$ kyears. Ages uncertainties that were used are standard errors on the mean. The symmetry of the curve indicates that, at the time of deposition, the OSL value of the sample was essentially erased. As the width of the Gaussian distribution is not so large, about 10.6 kyears, and most of the frequency is centered on the average, one can deduce that the deposition of this layer occurred within a short span of time.

The result of sample NS-28A (Fig. 3b) also presents a symmetrical frequency. Considering the Gaussian frequency curve, the age of this sample is about $65.0 \pm$ 2.4 kyears, and the average age was almost the same at
$65.5 \pm 2.4$ kyears. The coincidence of ages presented by samples NS-20A and NS-28A, from the GPA, reinforces the age of upper terrace of Ariaú river.

For sample NS-74B (Fig. 3c), the histogram presents a normal distribution centered at the age of $44.7 \pm$ 1.8 kyears. Curve symmetry maybe indicates that, at the moment of deposition, the OSL values were near to zero and the grains were practically bleached homogeneously. As with sample NS-20A (Fig. 3a), the width of the Gaussian distribution is about 10 to $15 \%$, and most of the frequency is centered near the average. In the frequency histogram of sample NS-143 (Fig. 3d), an irregular distribution was obtained and the values suggest that the deposition occurred within a time interval of between 8.9 and 13 kyears. The age of sediments from the GCC (sample NS-74B) indicates the beginning of the deposition in the Negro river.

Sample NS-268 mainly presented low age values, with the largest concentration at $1.6 \pm 0.1$ kyears and other smaller fluctuations dating up to 2.3 kyears. Based on stratigraphy data of E.E.A. Soares (unpublished data), the age of this sample should be intermediary between the ages obtained for samples NS-20A and NS143. Therefore, this low age is probably due to subaerial exposure of reworked sediments by the dynamics of secondary channels on alluvial plain. It should be noted that, currently, there are not sediments deposited above this unit.

The oldest fluvial terrace deposit of the Solimões river, represented by the sites NS-198 and NS-230 (Fig. 1, Table I), were also dated by OSL dating using the MAR protocol, yielding ages of $65.2 \pm 8.8$ and 60.7 \pm 6.6 kyears, respectively. These dates are compatible with those obtained from the oldest terrace deposits of the Ariaú river (from the GPA) (Fig. 3a and b), and reflect the beginning of the Quaternary sedimentation in the region, which relates directly to the establishment of meandering fluvial systems of the Solimões and Ariaú rivers during this time-interval. Deposits from the lower terrace, represented by the sites NS-242 and NS-238 (Fig. 1), yielded ages between $7.5 \pm 0.9$ and $34.5 \pm$ 4.4 kyears, respectively. The wide chronological interval of these lower terrace deposits is consistent with the time-interval obtained for the lower terrace deposition of the Ariaú river, from the GPA (site NS-143, Fig. 3d), 


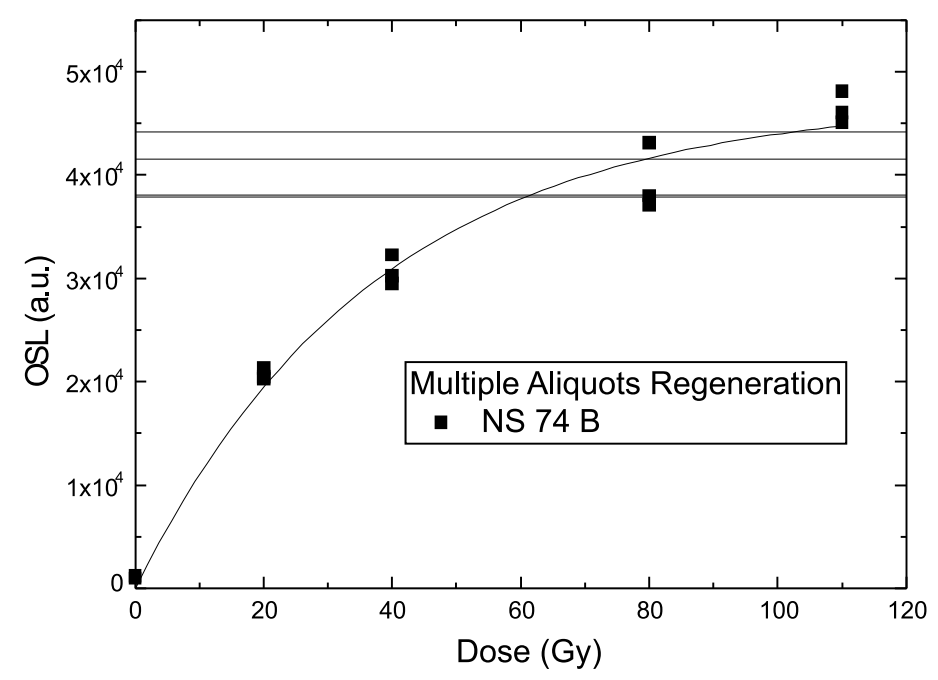

Fig. 2 - OSL calibration curve using the method of multiple aliquots and total regeneration method for the sample NS-74. See figure 1 for the location of the sample.

and at the same time it was recorded the final meandering phase of the rivers in the region. An older age (sample NS-030) of about 249 kyears was determined for intermediate terrace deposits of the Solimões river through extrapolation of the age intervals obtained for the upper and lower terraces. This result means that the OSL signal of the grains was not erased at the time of deposition probably due to rapid sedimentation and/or sub-aqueous transport.

Using the MAR protocol, the material from the GCP tectonic depression (Fig. 1) was dated at $427 \pm$ 44 kyears (sample NS-224) (Table I). The age of this material probably reflects the last period of sub-aerial exposure of the Miocene Novo Remanso Formation before the Pleistocene sedimentaion. During the exposure, the quartz grains had their previous OSL signal erased and were submitted to forceful ionizing radiation (cosmic rays and radioactive isotopes), which started a new accumulation of energy in the crystalline perimeter of the mineral.

\section{CONCLUSIONS}

The application of crystal luminescence dating methods in sediments, in accordance with the MAR and SAR protocols, has contributed to a better understanding of the tectonic-sedimentary evolution in the confluence of the Negro and Solimões rivers, in Central Amazonia.
Dating of approximately 430 kyears was determined for the material from the top layer of the Miocene Novo Remanso Formation in the GCP and indicates the last phase of sub-aerial exposure of this unit before the Pleistocene deposition.

The age of approximately 44 kyears obtained for sediments from the GCC indicates the beginning of sedimentation in the Negro river.

The OSL results for the deposits of fluvial terraces of the Solimões and Ariaú rivers revealed a continuous range of ages arranged along the analyzed units, which ranged from 65.2 to 7.5 kyears. This variation represents lateral accretion events that occurred during the phases of channel migration of fluvial systems in the region.

The chronological relation between the oldest fluvial terraces of the Solimões and Ariaú rivers in the GPA is an evidence of the first phase of establishment of meandering fluvial systems associated with the rivers in this region, occurring at approximately 65 kyears ago. The chronological interval of 34.5 to 7.5 kyears obtained from fluvial terraces of the Solimões and Ariaú rivers in the GPA indicates the maximum limit of persistence of the meandering systems formed by these rivers. The age variation obtained for deposits of the intermediate terrace of the Solimões river reflects the rapid deposition of fluvial bars, which could have avoided the extinction of the OSL signal in the grains of the deposits, thereby harming the outcome of the dating process. 


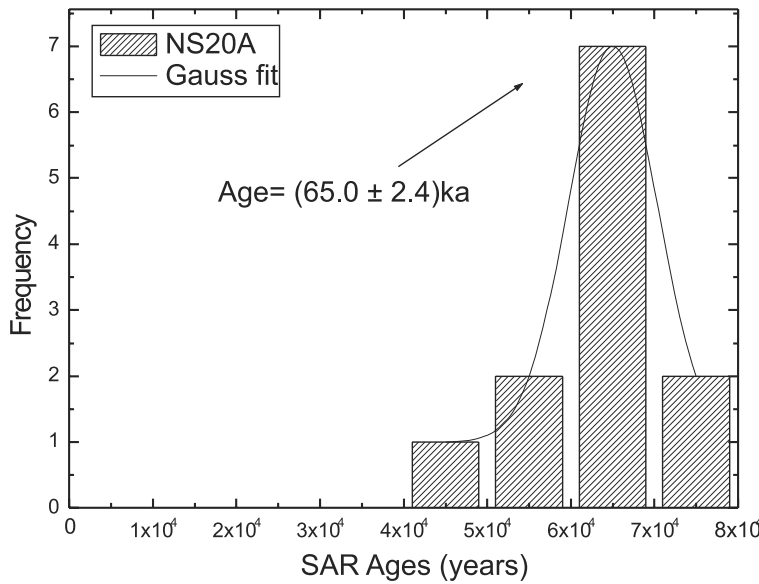

(a)

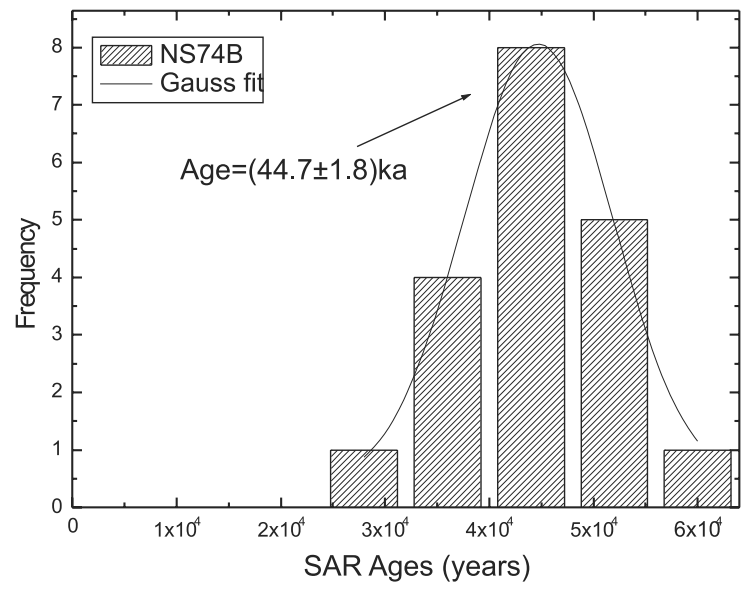

(c)

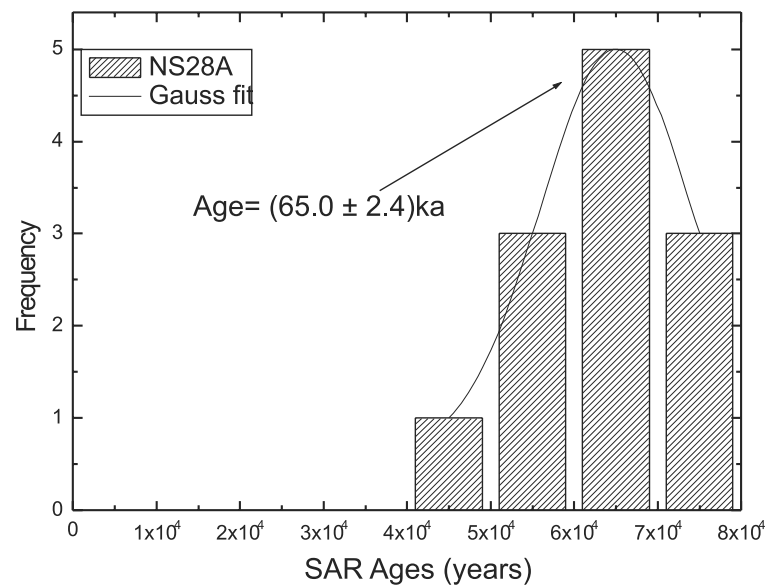

(b)

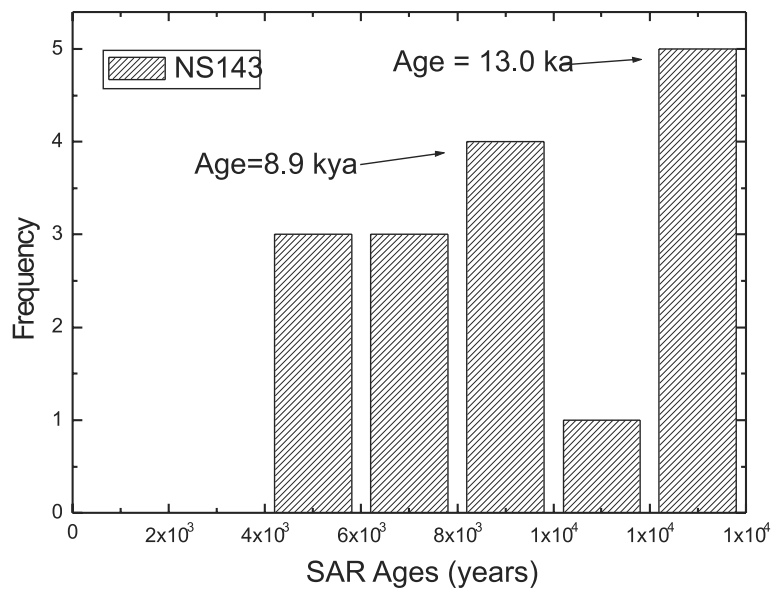

(d)

Fig. 3 - Histograms of ages utilizing the OSL method with SAR protocols for Quaternary sedimentary deposits of the alluvial floodplain of the GPA (NS20A, NS28B, NS143) and CGC (NS74) grabens.

\section{ACKNOWLEDGMENTS}

We thank the two anonymous reviewers for their constructive suggestions which helped in improving this paper. This study is a part of the doctoral thesis of the senior author developed with financial support of Coordenação de Aperfeiçoamento de Pessoal de Nível Superior (CAPES-PQI, grant 00044/03-2). S.H. Tatumi and C. Riccomini are research fellows of Conselho Nacional de Desenvolvimento Científico e Tecnológico (CNPq, Brazil).

\section{RESUMO}

Métodos de datação absoluta têm sido usados em estudos cronológicos de processos geológicos e unidades sedimentares de idade quaternária na Amazônia Central, Brasil. Embora as datações pelo ${ }^{14} \mathrm{C}$ tenham sido muito úteis na pesquisa arqueológica e estudos de solos, o intervalo de tempo abrangido por este método é ineficiente para avaliar aspectos da sedimentação e eventos geológicos do início do Quaternário na bacia Amazônica. O uso da datação por luminescência de cristais tem sido uma das ferramentas mais promissoras para a determinação da idade absoluta de depósitos quaternários na região amazônica. A datação por luminescência opticamente estimulada(LOE), seguindo os protocolos MAR e SAR, em um estudo tectono-sedimentar de depósitos aluviais quaternários da área de confluência dos rios Negro e Solimões, indicou idades de 1,3 (Holoceno) até aproximadamente 67,4 ka (Pleistoceno tardio) para estes sedimentos. Baixas concentrações de isótopos radioativos foram encontradas, com cerca de 2 ppm para ${ }^{235} \mathrm{U}$ e 
${ }^{238} \mathrm{U}, 5 \mathrm{ppm}$ para ${ }^{232} \mathrm{Th}$ e próximas a zero para ${ }^{40} \mathrm{~K}$. Uma comparação é feita entre os protocolos MAR e SAR considerandose os processos deposicionais fluviais envolvidos.

Palavras-chave: datação por luminescência de cristais, Quaternário, terraços fluviais, Amazônia Central.

\section{REFERENCES}

ABSY ML. 1982. Quaternary palynological studies in the Amazon Basin. In: PRANCE GT (Ed), Biological diversification in the tropics. New York: Columbia University Press, p. 67-73.

AitKen MJ And XIE J. 1992. Optical dating using infrared diodes: young samples. Quat Sci Rev 11: 147-152.

Barreto AMF, Suguio K, Bezerra FHR, TAtumi SH, YeE M AND GIANNINI PC. 2004. Geologia e geomorfologia do Quaternário Costeiro do Estado do Rio Grande do Norte. Geol USP Ser Cient 4: 1-12.

BASSINI F AND BECKER P. 1990. Charcoal's occurrence in soil depends on topography in terra firme forest near Manaus, Brazil. Biotropica 22: 420-422.

Behling H, Keim G, Irion G, Junk W and Mello JN. 2001. Holocene environmental changes in the Central Amazon Basin inferred from Lago Calado (Brazil). Palaeogeogr Palaeoclimatol Palaeoecol 173: 87-101.

Blum MD AND TöRnQvist T. 2000. Fluvial response to climate and sea-level change: a review and look forward. Sedimentology 47: 2-48.

Carneiro-Filho A, Schwartz D, TAtumi SH and RoSIQUE T. 2002. Amazonian paleodunes provide evidence for drier climate phases during the Late Pleistocene-Holocene. Quat Res 58: 205-209.

Carta Geológica do Brasil ao Milionésimo. 2004. Brasília: Ministério de Minas e Energia/CPRM/Serviço Geológico do Brasil.

Franzinelli E AND Igreja H. 2002. Modern sedimentation in the lower Negro River, Amazonas State, Brazil. Geomorphology 44: 259-272.

Franzinelli E AND Latrubesse E. 1993. The use of remote sensing in a neotectonic study in the Amazon Basin. Bull INQUA 16: 10-13.

FranZINELli E AND PIUCCI J. 1988. Evidências de neotectonismo na Bacia Amazônica. In: CONGRESSO LATINOAmericano de Geologia 7, São Paulo, Boletim de Resumos Expandidos, SBG, p. 80-90.

FrANZINELli E AND Rossi A. 1996. Contribuição ao estudo petrográfico e geoquímico do Arenito Manaus. In: SIM-
PÓSIO DE GEOlogia dA AMAZÔNIA 5, Belém, Boletim de Resumos Expandidos, SBG, p. 209-211.

Freitas HA, Pessenda LCR, AVAREna R, Gouveia SEM, Ribeiro AS AND Boulet R. 2001. Late Quaternary vegetation dynamics in the southern Amazon Basin inferred from carbon isotopes in soils organic matter. Quat Res 55: 39-46.

Freitas HA, Pessenda LCR, Avarena R, Gouveia SEM, Ribeiro AS AND Boulet R. 2002. Savana no passado da Amazônia. Cienc Hoje 32: 41-46.

Fuller IC, MACKLIN MG, LEWIN J, PASSMORE DG AND WINTLE AG. 1998. River response to high-frequency climate oscillations in southern Europe over the past 200 K.y. Geology 26: 275-278.

Giannini PCF, Guedes CCF, Assine ML, Angulo RJ, Souza MC, Pessenda LCR And TATumi SH. 2003. Variação transversal e longitudinal de propriedades sedimentológicas nos cordões litorâneos da ilha Comprida, litoral sul paulista. In: ABEQUA, 9, Boletim de Resumos, CD-ROM.

Hornborg A. 2005. Ethnogenesis, regional integration, and ecology in Prehistoric Amazonia. Curr Anthropol 46: 497-527.

Irion G, Rasanen M, Nunes de Mello JAS, Hoorn C, Junk W and Wesselingh F. 2005. Quat Res 64: 279-280, 2005. [Comments]. Rossetti D, Toledo PM AND GóES AM. New geological framework for western Amazonia (Brasil) and implications for biogeography and evolution. Quat Res 63: 78-89.

LATRUBESSE EM AND FRANZINELLI E. 1998. Late Quaternary alluvial sedimentation in the Upper Rio Negro River Basin, Amazon, Brazil: palaeohydrological implications. In: BENITO G, BACKER V AND GREORY K (Eds), Palaeohydrology and Environmental Change: J Wiley \& Sons, p. 259-271.

LAtrubesse EM AND Franzinelli E. 2002. The Holocene alluvial plain of the middle Amazon River, Brazil. Geomorphology 44: 241-257.

Lourenço RS, Montalvão RMG, Pinheiro SS, FerNANDES P, PEREIRA ER, FERnANDES CAC AND TEIXEIRA W. 1978. Geologia, geomorfologia, pedologia, vegetação e uso potencial da terra. In: BRASIL. PROJETO RADAM. Geologia da Folha SA.20 Manaus. Rio de Janeiro, RJ, DNPM, p. 17-164.

MaCHAdo JS. 2006. Dos artefatos às aldeias: os vestígios arqueológicos no entendimento das formas de organização social da Amazônia. Rev Antropol 49: 755-786. 
Martin L, Fournier M, Mourguiart P, Sifeddine A, TurCQ B, ABSy ML AND FleXOR JM. 1993. Southern oscillation signal in South American Paleoclimatic data of the last 7.000 years. Quat Res 39: 338-346.

Mozzi P, Azevedo MT, Nunes E AND Raposo L. 2000. Middle terrace deposits of the Tagus River in Alpiarça, Portugal, in relation to Early Human Occupation. Quat Res 54: 359-371.

MurRay AS AND Wintle AG. 2000. Luminescence dating of quartz using an improved single-aliquot regenerativedose protocol. Radiat Meas 32: 57-73.

Murray AS AND Wintle AG. 2003. The single aliquot regenerative dose protocol: potential for improvements in reliability. Radiat Meas 37: 377-381.

Nanson GC, Jones BG, Price DM and Pietsch TJ. 2005. River turned to rock: Late Quaternary alluvial induration influencing the behaviour and morphology of an anabranching river in the Australian monsoon tropics. Geomorphology 70: 398-420.

Page K, Nanson G and Price D. 1996. Chronology of Murrumbidgee River paleochannels on the riverine plain, southeastern Australia. J Quat Sci 11: 311-326.

Petersen J, Heckenberger M And Neves E. 2001. A Prehistoric Ceramic Sequence from the Central Amazon and its Relationship to the Caribbean. In: INTERNATIONAL CONGRESS FOR CARIBBEAN ARCHAEOLOGY 19, Aruba 1: 250-259.

PRescott JR And Hutton JT. 1994. Cosmic ray contributions to dose rates for luminescence and ESR dating large depths and log-term time variations. Radiat Meas 23: 497-500.

Rossetti DF, Toledo PM And Góes AM. 2005. New geological framework for Western Amazonia (Brazil) and implications for biogeography and evolution. Quat Res 63: 78-89.

SALDARRIAGA JG AND WESt DC. 1986. Holocene fires in the northern Amazon Basin. Quat Res 26: 358-366.

SANFORd JR RL, SAldarRiaga JG, Clarck KE, Uhl C AND HERRERA R. 1985. Amazon rain-forest fires. Science 227: 53-55.
SAntos GM, Gomes PRS, Anjos RM, CORDEIRo RC, Turce BJ, Sifeddine A, Di TAda ML, Cresswell RG AND FIFIELD JLK. 1999a. Utilização da técnica de AMS $-{ }^{14} \mathrm{C}$ em datação de fragmentos de carvão de solos, do Período Holoceno, na floresta Amazônica (região de Manaus). Rev Fis Apl Instrum 14: 1-11.

SANTOS GM, GOMES PRS, YOKOYAMA Y, Di TADA ML, Cresswell RG AND Fifield JLK. 1999b. Datação por

${ }^{14} \mathrm{C}$ utilizando espectometria de massa com acelerador de partículas. Rev Fis Apl Instrum 14: 18-26.

SCHAAN DP. 2007. Uma janela para a história pré-colonial da Amazônia: olhando além-e apesar-das fases e tradições. Bol Mus Para Emilio Goeldi Cienc Hum 2: 77-89.

Suguio K, Tatumi SH, Kowata EA, Munita CS and PAIVA RP. 2003. Upper Pleistocene deposits of the Comprida Island (São Paulo State) dated by thermoluminescence method. An Acad Bras Cienc 75: 91-96.

Sylvia DA AND GALlowAY WE. 2006. Morphology and stratigraphy of the late Quaternary lower Brazos valley: Implications for paleo-climate, discharge and sediment delivery. Sediment Geol 190: 159-175.

Tatumi SH, Grozzi G, Yee M, Oliveira Vi, SAllum AEM AND Suguio K. 2006. Luminescence dating of quaternary deposits in geology in Brazil. Rad Protec Dos 119: 462-469.

Tatumi SH, Silva LP, Pires EL, Rossetti DF AND GóEs AM. 2007. Datação de sedimentos Pós-Barreiras no norte do Brasil por Luminescência Opticamente Estimulada (LOE). In: Congresso DA ABEQUA 11, Belém, CD-ROM.

TeEuW RM And Rhodes EJ. 2004. Aeolian activity in northern Amazonia: optical dating of Late Pleistocene and Holocene paleodunes. J Quat Sci 19: 49-54.

TurcQ B, Suguio K, Martin L and Flexor JM. 1993. Registros milenares nos sedimentos dos lagos de Serra dos Carajás. Cienc Hoje 16: 1-35.

Turcq B, Sifeddine A, Martin L, Absy ML, SouBIEs F, Suguio K ANd VolkMer-Ribeiro C. 1998. Amazônia rainforest fires: a lacustrine record of 7.000 years. Ambio 27: 31-35. 